\title{
A NEW SPECIES OF EURYGASTER AND NOTES ON SOME LITTLE KNOWN SPECIES OF TURKISH PENTATOMIDAE (HEMIPTERA: HETEROPTERA)
}

\author{
By Niyazi Lodos ${ }^{1}$ \\ University of Connecticut, Storrs, Conn.
}

The species belonging to the genus Eurygaster Laporte are very important from the economic point of view in Turkey. Eurygaster integriceps Puton is one of the most harmful insects to wheat and barley, but in addition it also attacks rye, oat and other graminaceous plants. In Turkey it causes extensive damage especially in the eastern south provinces, the amount of injury caused varying from year to year and from place to place. In epidemic years the total amount of the losses in some areas can reach up to $90 \%$ if no control measures are used. Eurygaster maura (L.) and Eurygaster austriaca (Schrk.), found especially in Western Anatolia, cause damage approaching only $20 \%$ if no control measures are used, because their egg parasites are very active in this part of the country. A good knowledge of this genus is therefore very important to Turkish entomologists and agriculturists. While working at the University of Aegea, Izmir-Turkey, I paid special attention to these insects and collected many specimens whenever time was available. Amongst my material I find one new species which is described below.

\section{Eurygaster chinai n. sp. Plates 15 and 16}

General shape: oblong-oval, subdepressed (fig. I). General colour : reddish brown, except base of scutellum below pronotum which bears a narrow, blackish stripe transversally.

Structure (female): General shape of the head (fig. 2) subtriangular, about as broad between eyes as long, somewhat flattened on its surface except middle of tylus which is slightly prominent and regularly convex in front; lateral margins near eyes slightly sinuated and from eyes perceptibly narrowed and keeled; tylus long and somewhat broad, narrowed apically, truncate at the end; juga projecting slightly beyond end of the tylus, not in contact with each other, broadly rounded at apex; disc of head except margins finely and densely punctate. Antennae (fig. 3) brownish except fifth segment which is black-

\footnotetext{
${ }^{1}$ Present address: University of Aegea, Faculty of Agriculture, Izmir, Turkey.

Manuscript received by the editor February 25, 1963.
} 
ish ; first segment nearly clavate, almost equal to second ; second somewhat cylindrical; third shortest and cylindrical; fourth shorter than fifth and second in length and cylindrical; fifth longest and pubescent; length of antennal segments I, II, III, IV, V ; 30, 30, 2I, 28, 45. Eyes bright yellow except for middle which has a dark brown transverse stripe; inserted at posterior margin of the head, not prominent but also not contiguous with pronotum; ocelli brownish, inserted fairly far from base of head and somewhat prominent. Rostrum thick and nearly reaching to the middle of hind coxae, brownish except the last segment which is blackish.

Pronotum fairly broad, more than twice as broad as long in the middle and flattened (fig. 4), anteriorly nearly straight, a little broader than the eyes and head together, lateral margins slightly sinuate, humeral angles somewhat pointed, lateral margins slightly keeled, and pale in colour, without punctures; posterior margin of pronotum at base of scutellum concave; disc of pronotum finely and densely punctured; in middle of disc a large, long transverse prominence (fig. $\mathrm{I}, 4,5)$; in front of the prominence two somewhat low impressions; behind it, two somewhat strong impressions; cicatrices light yellowish, large, punctured finely and obscured. Scutellum nearly parallel at the sides and sinuate towards the middle, at the apex regularly rounded; distinctly shorter than abdomen; at each basal angle there is a strong narrowed impression; base of scutellum against pronotum with a blackish somewhat wide transverse stripe (fig. I, 4); each basal angle with a whitish callus located some distance from the base of pronotum; colour of base of scutellum brownish, gradually paler toward apex; puncturations near and around of calli largest and gradually disappearing far from these areas; middle of scutellum an obscure longitudinal carina. Clavus very small and punctured. Corium somewhat strongly punctured, extending beyond middle of the scutellum, same colour as that of scutellum and other parts of the body; outer vein of the corium distinct and reaching nearly to the apex of corium. Membrane transparent, reaching just to apex of scutellum. Connexivum a little broader than thorax, darker than scutellum and other parts of body, surface irregular; finely and densely puncured, outer margins of each connexival segment distinctly rounded. Underside of head, sternum and acetabula strongly punctured. Venter light brownish, without or with only obscure punctures; underside of each connexival segment with a blackish spot near margin. Spiracles reddish. Female genitalia with a distinctive structure as seen in fig. 6 . Valvifer I large, nearly triangular and each one has small blackish 


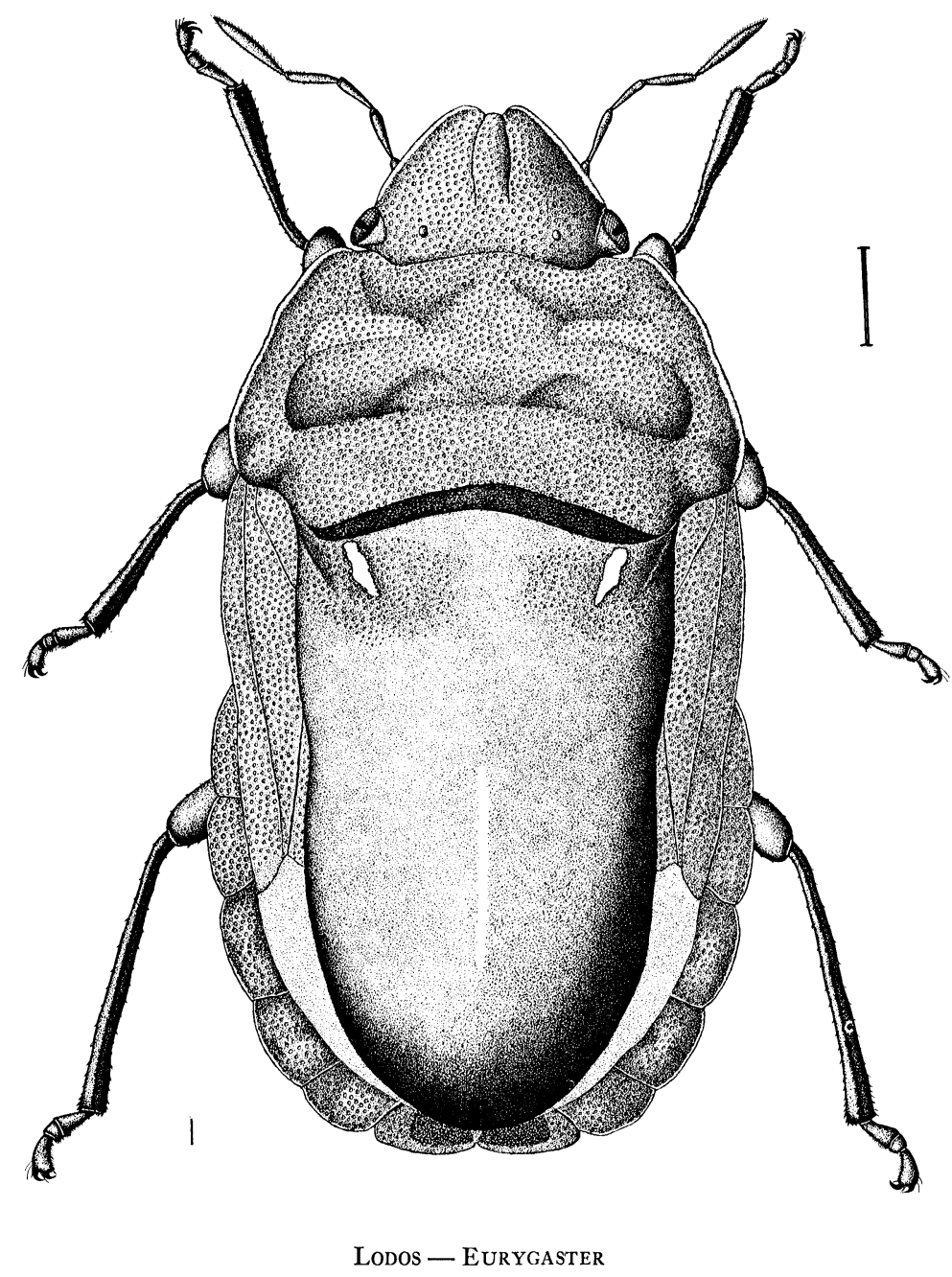


stripe near distal end; paratergite 9 large and some distance from the margin of seventh sternal segment; valvifer II triangular. Legs light brown; tibiae almost straight and with a few very small and obscure spines; at the apex, spines become closer and with few hairs; tarsus normal for the genus, underside with thin, dense and short hairs; second tarsal segment shortest; third with a few hairs at apex; claws dark brown $3 / 4$ from the base (fig. 2 ).

Size (female): length $12 \mathrm{~mm}$.; maximum width across abdomen $7.2 \mathrm{~mm}$., head: length $2.4 \mathrm{~mm}$; width $2.9 \mathrm{~mm}$.; vertex $2.5 \mathrm{~mm}$., pronotum: length $2.7 \mathrm{~mm}$.; width $7 \mathrm{~mm}$., scutellum: length 6.7 mm.; width $5 \mathrm{~mm}$.

Holotype: female, Turkey, Izmir-Bornova, r4.V.I958 (N.Lodos), in the British Museum (Natural History).

Habitat: the type, a female was found by me by sweeping on wild graminaceous plants in a wooded hill formation. It seems to be a very rare species and the male is unknown.

This new species is related to Eurygaster integriceps Put. by external appearance but can easily be distinguished by its distinct prominence on the pronotum, shorter scutellum, distinctly rounded connexivum and particularly the structure of the female genitalia. I name this species after the outstanding British authority on the Hemiptera, Dr. W. E. China, who has helped me a great deal in my entomological work.

\section{Solenostethium bilunatum (Lefebure)}

Scutellera bilunulata Lefebure 1827, Mém. Soc. Linn. Paris, :102; pl. 5, f. 5.

This species was first recorded from Turkey by Fieber (I86I) as Coeloglossa ledereri without specific location. Lethierry and Severin (1893) also listed it in the same way. Oshanin (1912) was the only one to express the locality more definitely as "Turkei (in Europa)" which at that time was Thrace. So far as is known Solenostethium bilunatum (Lef.) is a Mediterranean element which extends from Tunisia, Morocco, Algeria, Cyprus, Turkey and Syria. It is obvious that it could not have existed so far north as Oshanin states. Its northern range was not previously even as far north as Izmir (Turkey). This species has remained known to Turkey only from these early records until the present time.

The writer now is able to confirm the presence of this species in the Turkish fauna. I have collected I4 female and I I male specimens at

Explanation of Plate 15

Fig. 1. Eurygaster chianai n. sp. female (holotype). 

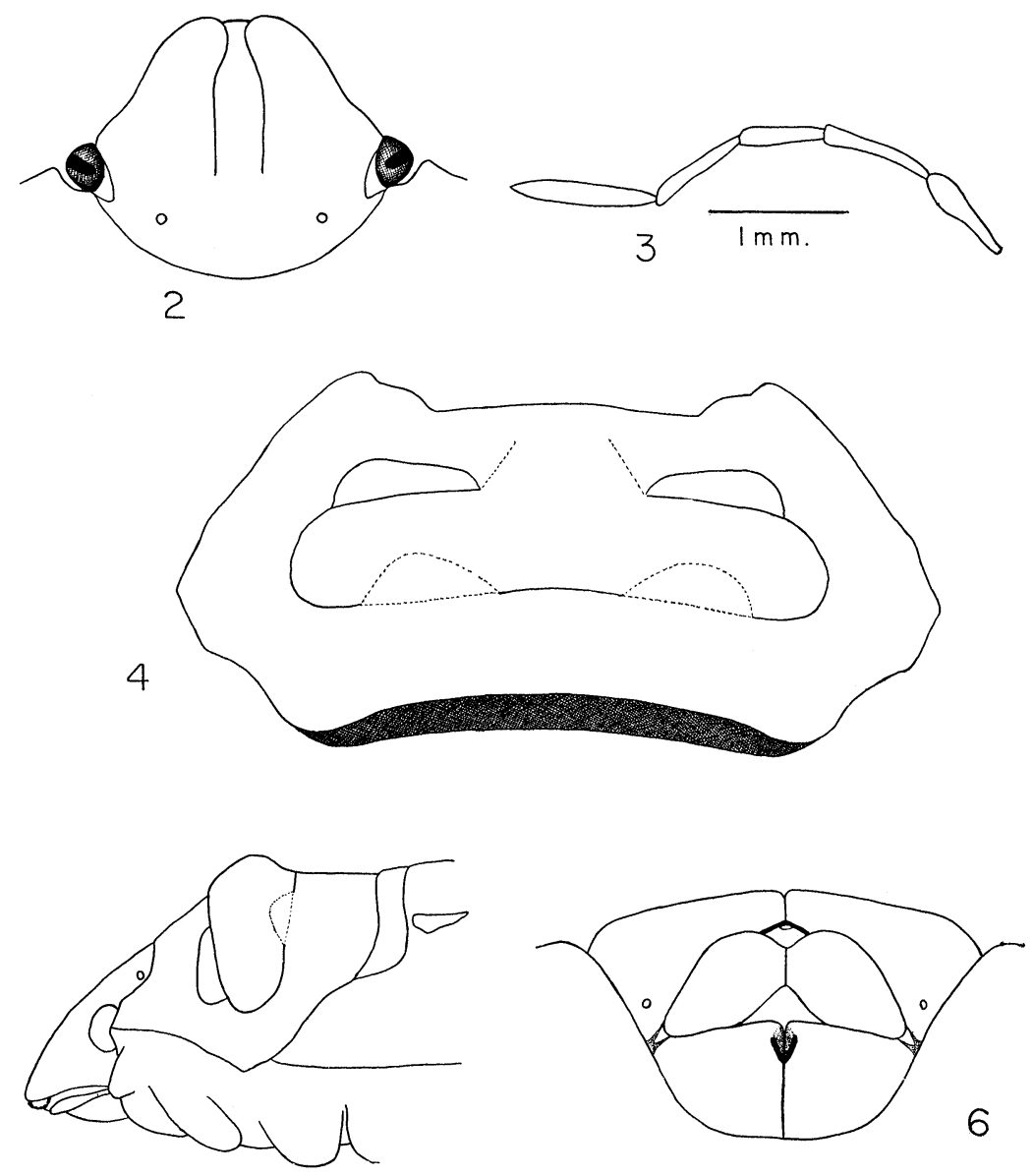

5

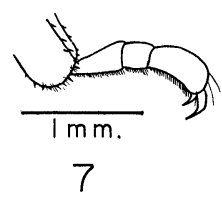

LODOS - EURYGASTER 
Dalaman-Muğla (Turkey), 23.VI.1962, and some specimens at Köycĕgiz-Muğla (Turkey), 2r.VI.rg62. All these specimens were taken from Paliurus spina-christi Miller. These specimens are deposited in the personal collection of the author and the Aegean University, Faculty of Agriculture collection in Izmir (Turkey).

In 186 I Fieber described Coeloglossa ledereri from 7 specimens (male and female) and cited its distribution as Turkey and Syria without any specific locality. Fieber's description seems rather meagre, having some characteristics of Solenostethium bilunatum (Lef.) and some Solenostethium ledereri Fieb. These characteristics are based on the formation of clypeus, the colour of the dorsum of the insect and the existence of black spots on the head. Solenostethium ledereri Fieb. is now considered at the most as a colour form of Solenostethium bilunatum (Lef.) (Stichel I960).

I have examined specimens from Dalaman which I collected at the same locality and discovered that while there are some different characteristics attributable to Solenostethium bilunatum (Lef.) and Solenostetium bilunatum f. ledereri Fieb., these different characteristics are not at all constant. Therefore, Solenostethium bilunatum f. ledereri Fieb. is here considered as a straight synonym (new synonymy).

\section{Pausias martini Puton}

Piezodorus martini Puton 1890, Rev. d'Ent., 9:227.

This species has only recently been included as a part of the Turkish fauna, although its geographic range includes Syria and Caucasia (Puton 1890, Oshanin 1912, Vidal 1949, Stichel 1960 and Linnavuori 1960). This distribution shows that it should also be found within the boundaries of Turkey. Wagner (1959) has recorded this species from Turkey for the first time. He reported if from Diyarbakir, which is in the south east of Turkey. The locality is some $200 \mathrm{~km}$. from the northern border of Syria. The author is now able to establish the presence of this species on the Aegean sea coast in Western Anatolia. One male and 2 female specimens were collected from Karsiyaka-Izmir (Turkey), Io.VIII.I96o, from a mulberry tree (Morus alba L.). Thus the range of this species is spread over a considerable part of Turkey.

Explanation of Plate 16

Fig. 2-7. Eurygaster chinai n. sp. female (holotype); 2, dorsal view of the head; 3 , antenna; 4 , dorsal view of pronotum; 5 , lateral view of pronotum; 6. female genitalia; 7 , hind tarsus. 


\section{ACKNOWLEDGEMENTS}

While preparing this work I used the collections and library of the British Museum (Natural History) and the laboratory and library of the University of Connecticut, Department of Zoology and Entomology. To these institutions the author expresses his sincere appreciation. My thanks are due to Dr. J. A. Slater for his kind help and the loan of literature. I also appreciate help received from Dr. W. E. China, especially for valuable opinions on the subject and for reading the typescript.

Fieber, F. X.

\section{References Cited}

1861. Die Europäischen Hemiptera (Rhynchota Heteroptera). Nach der analytischen Methode bearbeitet. Wien. Carl Gerhold's Sohn.

HOBERLANDT, L.

1955. Results of the zoological scientific expedition of the National Museum in Praha to Turkey. Acta Ent. Mus. Nat. Prague, Supp. 3, $264 \mathrm{pp}$.

Horvath, G.

1895. Hemiptera nova Turkestanica. Termesz. Füzet. 18:221-225.

JAKOVLEV, B. E.

1885. Materials for the Hemipterous fauna of Russia and neighbouring countries. Bull. Soc. Nat. Moscau, 61 (3):78-90.

LethierRy, L. ET SeVERIN, G.

1893. Catalogue général des Hémiptères, tom I, Hétéroptères, Pentatomidae. F. Hayez. Imprimeur de l'Académie Royal de Belgique, Rue de Louvain, 12:1-194.

LINNAVUORI, R.

1953. A Palearctic Heteropterous material collected by Sahlberg and U. Saalas. Ann. Ent. Fenn. 19:147-167.

1960. Hemiptera of Israel. Ann. Zool. Soc. "Vanamo", 22 (1) :1-71.

Montandon, L.

1885. Description de deux nouveaux Eurygaster. Rev. Ent. Caen. 4:171172.

OSHANIN, V.

1912. Katalog der Palearktischen Hemiptera (Heteroptera, Homoptera, Auchenorrhyncha und Psylloidae). Berlin. Verlag Von R. Friedländer \& Sohn, $187 \mathrm{pp}$.

Puton, A.

1881. Enumeration des Hémiptères recoltés en Syrie par Abeille de Perrin, avec la description des espèces nouvelles. Mitth. Schw. Ent. Ges. 6:119-129.

Ribaut, H.

1926. Caractères distinctif des Eurygaster maura et Eurygaster meridionalis. Bull. Soc. H. Ent. Nat. Toulouse, 54:103-121.

STICHEL, W.

1960. Illustrierte Bestimmungstabellen der Wanzen. II Europa. BerlinHermsdorf, Martin-Luther-Strasse 4 (39): 42-660.

VIDAL, J.

1949. Hémiptères des l'Afrique du nord et des pays circum Mediterranien. Mém. Soc. Sci. Nat. Mar. $48: 1-238$.

W AGNER, E.

1959. Beitrag zur Heteropteren-fauna Anatoliens. Z. Ang. Ent. Hamburg, 44: 102-113. 

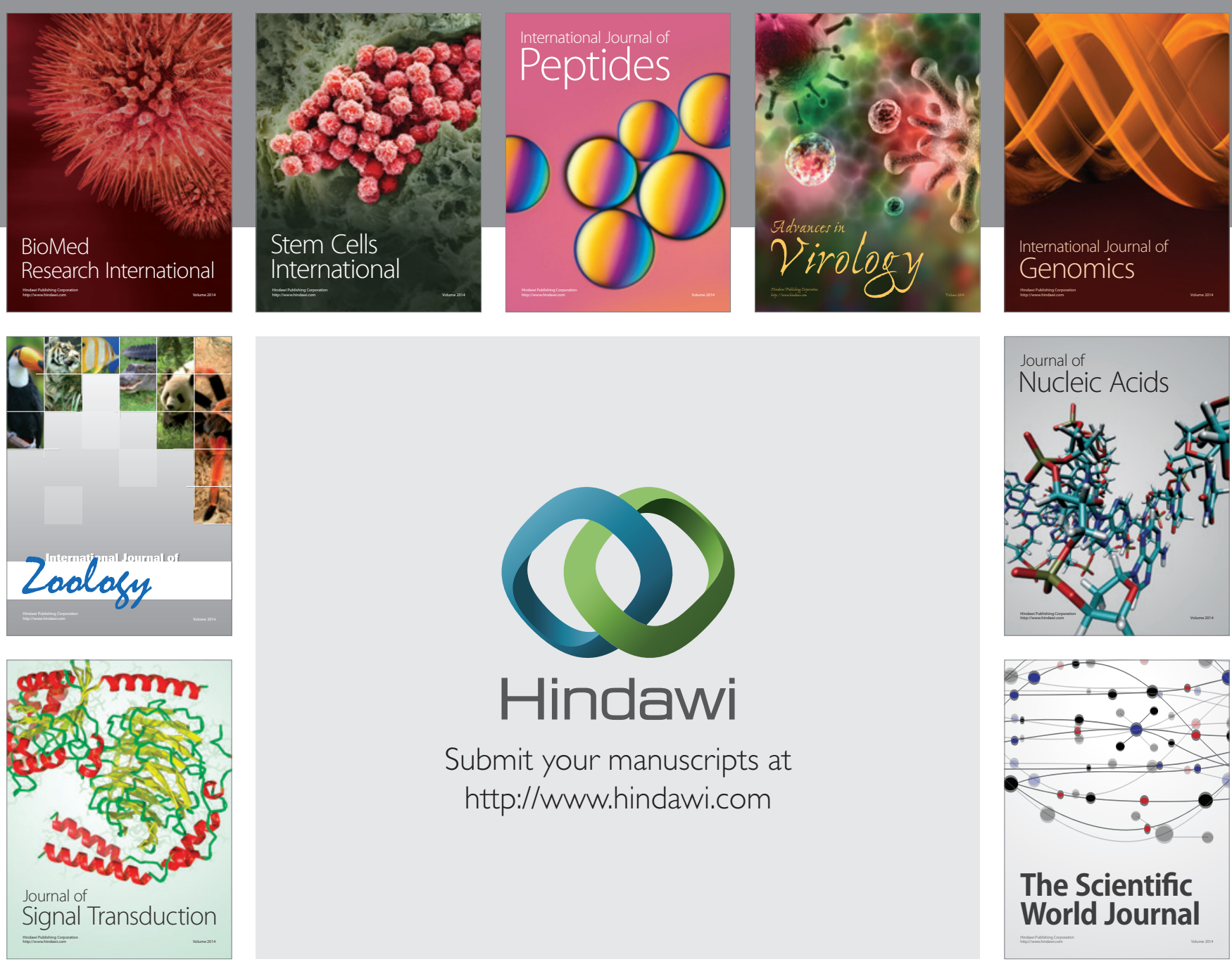

Submit your manuscripts at

http://www.hindawi.com
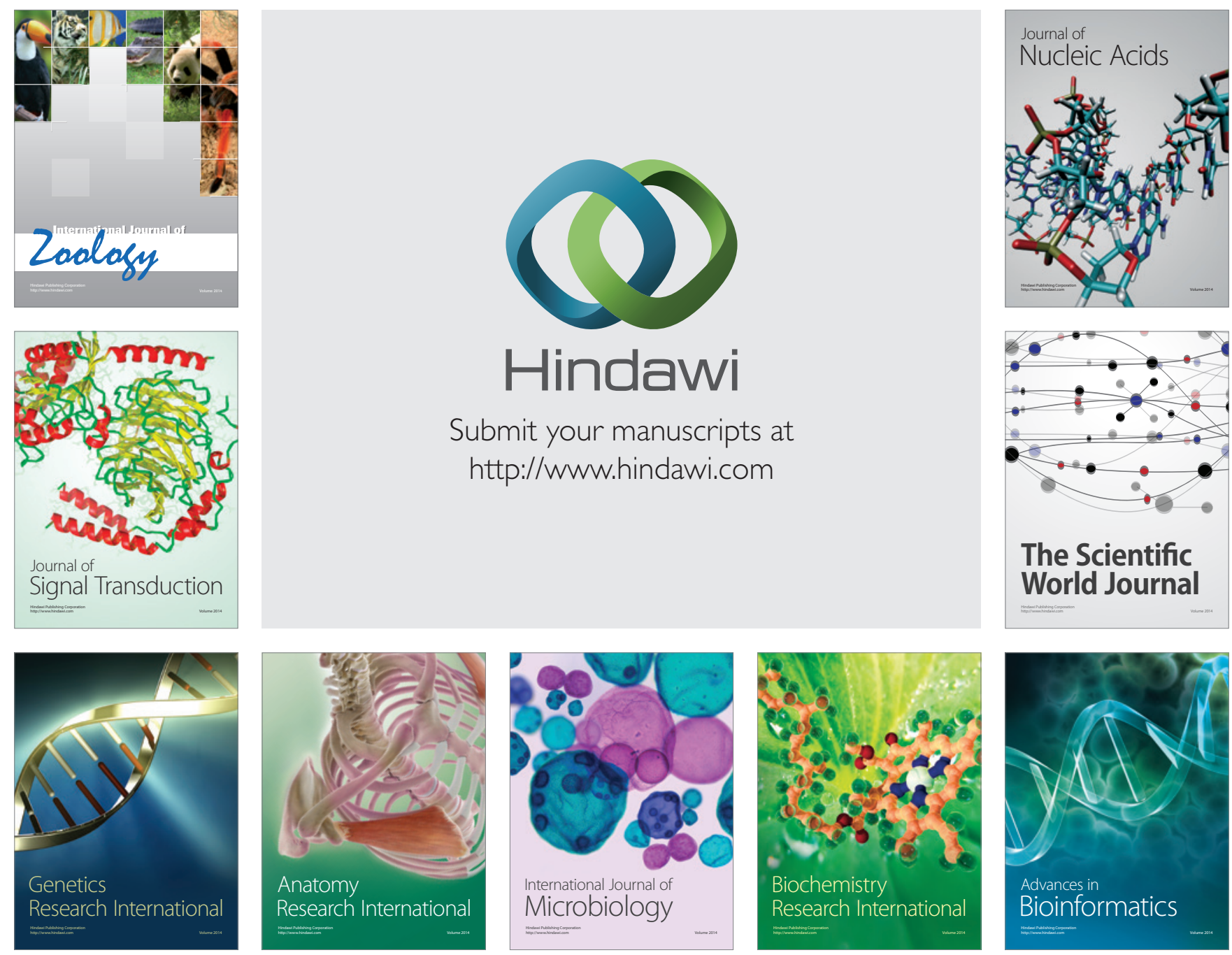

The Scientific World Journal
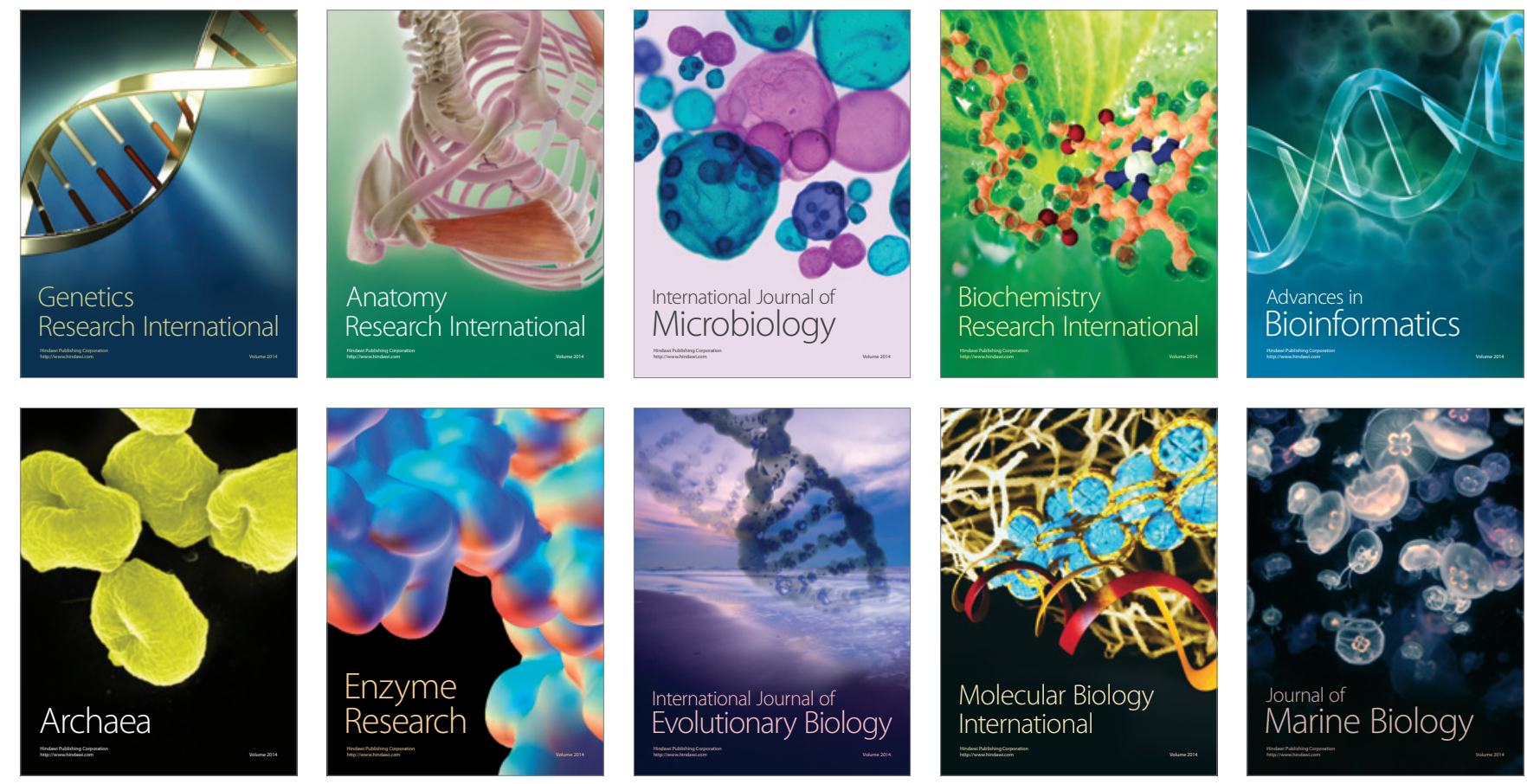